\title{
Effectivness on the Use of IPA Funds in Albania Covering the Period 2014-2016
}

\author{
Jola (Himci) Kepi, (PhD Candidate, MBA) \\ University of Tirana /Prime Minister's Office, Albania
}

Doi:10.19044/esj.2018.v14n31p191 URL:http://dx.doi.org/10.19044/esj.2018.v14n31p191

\begin{abstract}
The utilization of foreign aid and especially EU funding in Albania has been of high interest by both the Government and Developing Partners on their use, transparency and accountability on mobilization on effective use of development resources in the country. This paper intends to provide an analytical overview of development partners' activities in Albania especially the European Union covering the period 2014-2016, mapping of their support in a variety of sectors, as well as the impact of their support in line with country priorities and the achievement of country's objectives toward the European Integration. First we look at the effectiveness of external aid as a whole in different sectors and make an analyses of the contribution per donors and especially EU and secondly, we analyze the fact of the EU contribution is it good and enough source to stimulate economic growth in Albania in line with the European Agenda. The finding shows that financial resources are not fully absorbed by the country and there is a need to establish and strengthening the Integrated Policy Management Group (IPMG) per each sector as e mean to monitor, influence and recommend areas of intervention in order to increase the effectiveness and the external use of the financial resources available.
\end{abstract}

Keywords: External Assistance, EU Funds, Aid Effectiveness

\section{Introduction:}

External assistance is a process which dates more than fifty years ago by developed countries in supporting and stimulating economic growth in the developing countries. After collapse of Communism Regime the interest of EU and other developed countries has established relation and supported Albanian transition in performing economic growth. Albania realized that joining European Union family as the only hope for development and integration postcommunism and thus committed itself to its European dream. Albania -EU relation dates back in 1991 with the establishment of diplomatic relations Albania-EU until nowadays that holds the status of candidate country and 
awaits for the positive recommendations by EC to start the opening of the negotiations. Since 1991 enormous amount of financial support has been given to the country in aligning its policies and economy with the integration process. We will analyze the effectiveness of the use of IPA funds in Albania taking into account other donor's contributions per sector covering the period 20142016.

The Government of Albania is in the process of implementing a comprehensive management information system (MIS) in order to automate the Government business processes for the usage of external assistance. External Assistance Management Information System (EAMIS) will serve as a reliable and credible source of information on overall donor, public, private and local investments in Albania's development and economic growth. It is designed to support the Albanian authorities to reduce efforts and transaction costs in gathering and analyzing data, producing reports on external assistance and evaluate the effectiveness of foreign Aid in supporting the Albanian economic growth.

The Global Partnership - a forum created following the commitments made in Busan (Korea, 2011), makes a change in paradigm, shifting from "aid effectiveness" to "development effectiveness". The findings of the 2016 Monitoring Report for Albania of the Global Partnership for Effective Development Co-operation (GPEDC) are an integral part of this report.

The external assistance coordination efforts alone will not achieve significant development results unless they are effectively integrated in national development planning, governance structures and systems, which are all important elements of the Integrated Planning System (IPS) in Albania. In order to achieve development results, and evaluate effectiveness several steps have been taken by the government to enhance this system by introducing the Integrated Sector Approach Mechanism, or, the so called Integrated Policy Management Groups (IPMG). The IPMG Mechanism has been strongly supported by the EU in order to have a clear picture on policy deliberations as an efficient approach to plan and use several types of financial resources according to the sector needs.

Latest observations as at the way the external funds have been used so far in Albania, shows that the Government and our country's development partners will continue the dialogue that will help increase the impact, efficiency and effectiveness of the use of the external assistance.

\section{Part I: Literature Review, Methodology and Limitations}

The Paris Declaration on Aid Effectiveness adopted in 2005 is a milestone for international efforts to increase the effectiveness of aid through harmonization, alignment, and strengthening country ownership. 
Albania, is one of the pilot countries for monitoring progress against the Paris Declaration since 1990 on effectiveness of external assistance. The measure of the amount of foreign financial assistance in a country like Albania is measures by the absorption capacity of the country. The absorption capacity in Academic Literature is seen as one of the main constrains a country faces in utilizing the use of external affairs. Authors such as Herve and Holzmann (1998) define the notion of "absorption capacity" as the lack of administrative and institutional capacity. For Šumpikova et. al. (2004), stands for the extent to which a country is able to fully utilize the allocated financial resources from the other donors and especially the EU funds in an effective and efficient way. Other definitions state that the absorption capacity represents the ability of a country to absorb all the allocated external funds, with more emphasis on quantitative aspects. Mrak and Tilev (2008) state that the absorption capacity denotes the degree to which a country is able to effectively and efficiently spend the financial resources from the EU in order to make significant contribution towards economic and social cohesion. As per the European Commission, absorption capacity means the capability of a country to use allocated funds in an efficient way. Horvat (2003) concludes that the definitions of absorption capacity is usually based on different evaluation studies and reports prepared for the European Commission. For the purpose of this article, the absorption capacity stands as main factor to which Albania is capable of utilizing financial resources from the EU pre-accession programs.

The methodology used in analyzing the effectiveness of use of IPA funds in Albania for the period 2014 -2016 is performed primarily on analyzing the system and mechanisms for managing the Development Cooperation with external developing partners (donors); Secondly the data sources consist of the donors' database managed by the Development for Development and Foreign Aid, while secondary data sources include OECD/DAC database, the NSDI 2015-2020, and the 2016 Monitoring Report for Albania of the Global Partnership for Effective Development Co-operation (GPEDC). The analysis of the past trends of external assistance before year 2014 has been considered as desk study and review.

Nevertheless, despite efforts to produce a reliable analyses of donor assistance for the period 2014-2017, some limitation concerning data's for the year 2017 have occurred. For this reason, the study analyses the datas covering the year 2014-2016.

\section{Development Cooperation in Albania in the IPS context}

The Government of Albania (GoA) adopted the Integrated Planning System (IPS) in November 2005, as a set of operating principles which ensure that government policy planning and monitoring takes place in as efficient and harmonized way as possible. IPS is the key national decision-making system 
for determining strategic direction and the allocation of recourses. The core processes that cover all government organizations and activities include the 1) National Strategy for Development and Integration (NSDI), which establishes the government's medium to longer term goals and strategies for all sectors based on a national vision; 2) Medium-Term Budget Programme (MTBP), which requires each ministry to develop a three-year plan to deliver programme outputs to achieve its policy objectives and goals within its expenditure ceiling as set out in the government's fiscal plan. Public investment are also included and integrated into MTPB procedures. 3) European integration encompasses processes that include Stabilization Association Agreement (SAA) implementation, Instrument for Pre-Accession (IPA) and the translation process of Acquis Communitaire. Its requirements feed into the formulation of sector and crosscutting strategies that are translated into outputs through MTBP processes under the IPS umbrella.

Establishment of the Integrated Sector Approach Mechanism (IPMG) has been an initiative undertaken by the Government of Albania since 2014, aiming to support institutional and operational measures for the implementation of the integrated sectorial approach, in the framework of the Integrated Planning System (IPS). Since

\section{National Strategy on Development and Integration and the linkage with Sustainable Development Goals}

The National Strategy on Development and Integration 2015-2020 (NSDI) is the medium to long-term vision document for social, democratic and economic development in Albania. The NSDI is a key component of the Integrated Planning System (IPS), which constitutes a set of operating principles to ensure that government policy planning and implementation take place in a coherent, efficient and integrated manner. The NSDI along with sector strategies, crosscutting strategies, master plans and action plans form a comprehensive strategic development framework at the national level. The vision of NSDI is based on the achievement of six strategic policy priorities. Each priority focuses on a main dimension of national development and integration and is subsequently translated into strategic objectives, anticipated results, outcomes and impacts. NSDI is linked with 6 Government Priorities which are (i) Delivery of innovative, citizen-centred public services, (ii) Recovery and financial consolidation of the power sector, (iii) Integrated water management, (iv) Improving innovation and enhancing competitiveness (v) Integrated land management and (vi) Fiscal structural reform

NSDI presents strategic development objectives, sets sectorial and area-specific targets capturing available financial opportunities and ensures linkage to the SDGs. 
The 2030 Agenda for Sustainable Development includes a set of 17 SDGs to end poverty, fight inequality and injustice, and tackle climate change by 2030. The Sustainable Development Goals build on the Millennium Development Goals (MDGs), however, the new SDGs go much further than the MDGs, addressing the universal need for development.

In September 2015, the Government of Albania committed to implement the Agenda for Sustainable Development Goals 2015-2030. Substantial progress has already been made in mainstreaming the NSDI with the governance indicators under SDG 17, introducing a full set of governance indicators, with baseline, targets and sources of information, organized around the NSDI pillars and already available to be used at the national level. NSDI Monitoring framework will also be used to monitor the SDG indicators.

\section{External Assistance Coordination Architecture}

Over the last decades, considerable momentum is built around the establishment of common external assistance coordination architecture, and Government and development partners have collectively and individually established a mechanism for increased coordination and effectiveness.

The importance of development cooperation and sector coordination both of which go beyond mere aid or donor coordination - has been highlighted in recent years and have heavily influenced the preparation and concluding analysis during the recent High Level forums and Meetings on Development Effectiveness (Busan, 2011 and Mexico City, 2014, re-enforced in Nairobi, 2016).

At the political level development cooperation functions are led by the Prime Minister Office. At a technical level these functions are performed by the Department for Development, and Foreign Aid (DDFA) within the Prime Minister's Office. DDFA's role and structure has been gradually enhanced and extended in order to build partnerships among all development partners including donors, IFIs, development agencies, civil society organisation, private business etc. DDFA together with the Donor Technical Secretariat lead the monitoring process for the effectiveness of development cooperation, launched by the OECD/DAC and Global Partnership for Effective Development Co-operation.

The Donor Technical Secretariat (DTS) was created in early 2004, as a collective initiative of donors in Albania to facilitate stronger information exchange between development partners and the Government, in order to improve aid effectiveness and assist the Government in assuming greater national ownership for the donor co-ordination process. Currently, the DTS is composed of four multilaterals: EUD, OSCE, WB, and UNDP who are permanent members; and three bilaterals: Germany, Italy and Sweden (2015). 
It is chaired by the EU Delegation and supported by an expert - currently funded by the EU Delegation.

The Development and Integration Partners (DIP) meeting is a technical forum, where bilateral and multilateral development partners and government representatives meet regularly to discuss and take decisions on various development co-ordination issues. DIP meetings are organised on quarterly basis and co-chaired by the DTS chair and the DDFA Director. They can also be called in ad-hoc basis to discuss emergent issues. The main topics of discussion relates to the Integrated Planning System, Government reforms and priorities, national and sector strategies, development financing and other issues of development cooperation. While at the sector level, development cooperation issues are discussed at the Integrated Policy Management Groups (IPMG).

\section{Integrated Sector Approach Mechanism (or IPMG Mechanism)}

Policy coordination improved with the establishment of Integrated Policy Management Groups (IPMG) in four pilot sectors. It evolved important platforms for policy deliberations as well as an efficient approach (SWAp) to plan and use several types of financial resources according to the sector needs.

IPMG is part of the IPS System. It aims to fill in the existing gaps within the IPS System, especially towards strengthening the integrated management process, integrated recourses, building partnerships including central and local government, external assistance, business and development partners through a) Presentation of Government sector priorities in the heart of policy and planning processes, and insuring government leadership and ownership, b) Translation of strategy and policy documents in cross-cutting, costed and financed programs, based on results,c) Development of the National Sector Programs (NSP) with concrete measures and actions for implementation based on defined indicators leading to the agreed outcomes and results. d) Insuring linkages between different structures, recourses and performance oriented processes and e) Insuring transparency and accountability towards partners and public

Following a period of preparation, the Integrated Sector Approach Mechanism was established on a pilot basis by Prime Minister's Order No 129 , dated 21 December 2015 supported by EU delegation team in Albania. Four pilot IPMGs have been established already: Competiveness \& Innovation; Integrated Water Management; Employment and Social Policies; Good Governance and Public Administration Reform. 


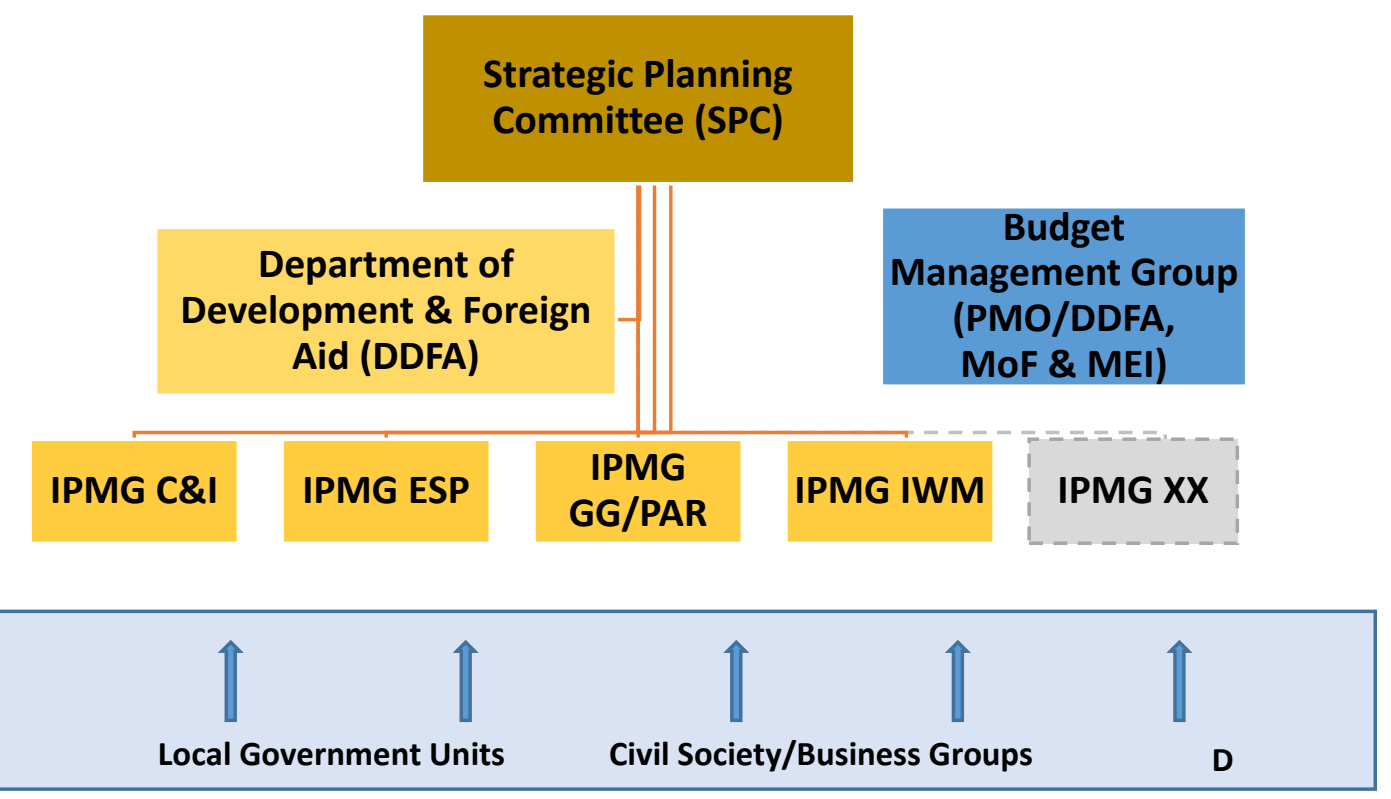

Figure 1: The Architecture of IPMG

The IPMG system aims to provide the Strategic Planning Committee (SPC) and other high-level government committees with the necessary recommendations for key policy decisions affecting those sectors deemed a priority and that require cross-ministerial cooperation.

IPMG and Thematic Groups (ThG) meetings have been organised a few times/year for insuring broad partnership on usage of IPA funds, joint programing and funding (including IPA SBS), joint management and action. Furthermore, the UN Program is designed to align its own "Delivering as One" management structure to these IPMGs, in order to enhance cross-sectorial policy development and SDGs mainstreaming.

Such progress prepared the bases for further expansion of the mechanisem covering the full specter of sector policies. A new Regulatory Framework will be approved to consolidate the current IPMG-s and further roll-out of the mechanism.

\section{Development Coordination Tools}

The Government of Albania is in the process of implementing a comprehensive automated system to strengthen public financial management within the Integrated Planning System (IPS).

External Assistance Management Information System (EAMIS) is designed to support the Government of Albania in effectively managing of development funds, and, promoting accountable and transparent use of resources. The system will serve as a reliable and credible source of information for externally funded activities. It will also serve as a one-stop- 
shop for getting information on foreign aid projects and strategic investments projects as FDI and concessions /PPP, In Albania. The EAMIS system will be an integrated nation-wide system used by Government Institutions a and development partners, providing all the stakeholders with facilities for data entry, analyses, reports and monitoring of effective usage of these funds.

\section{Part II: Analysis on external assistance portfolio in Albania for the period 2014-2016}

\section{A General outlook on external assistance in Albania}

Foreign financing portfolio17 in Albania during the period 2014-2016 amounted up to $€ 5.29$ billion, from which projects worth up to $€ 1.29$ billion are completed, $€ 2.85$ billion are ongoing, and $€ 1.15$ billion are still in planned status.

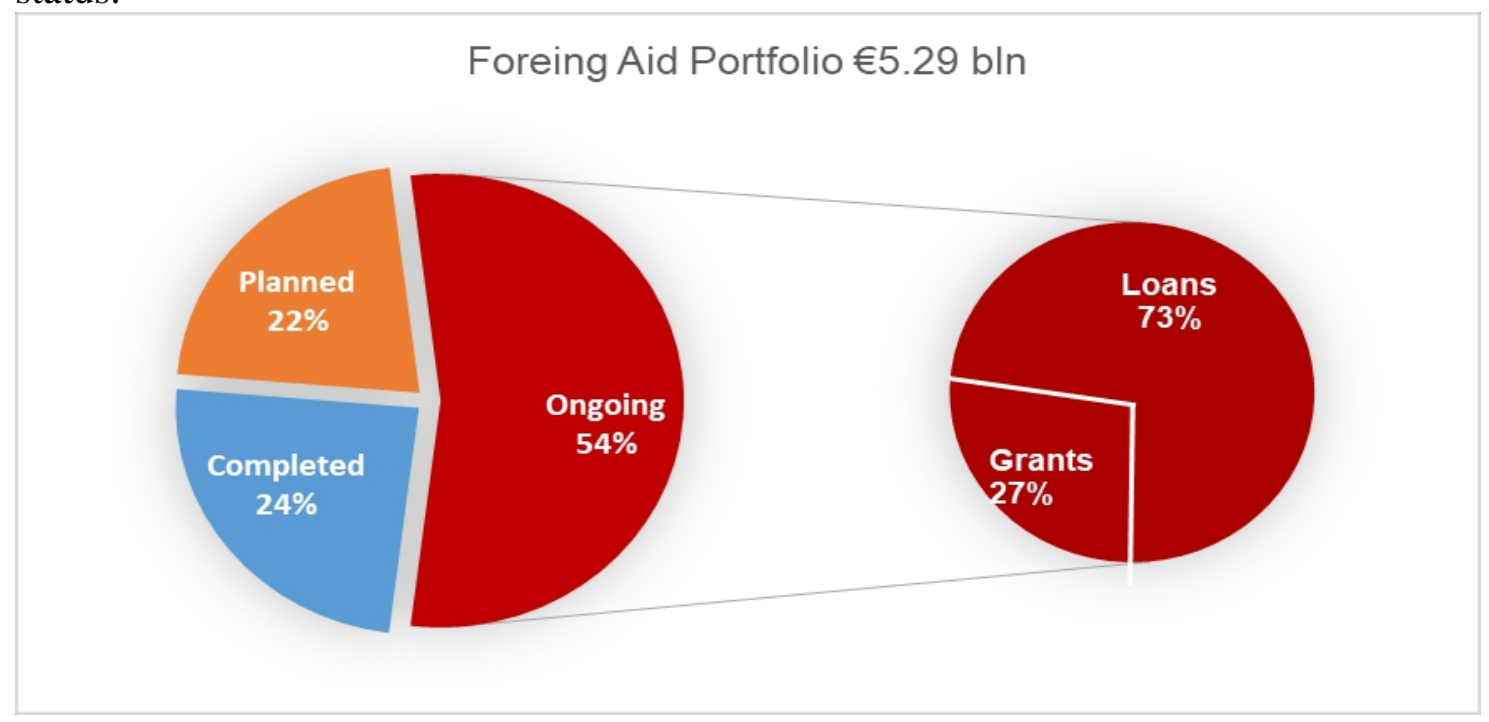

Figure 2: Foreign Aid Portfolio 2014-2016

Reviewing the level of new commitments over the last three years (2014-2016), a strong fluctuation has been observed as result of a new programing cycles negotiated during 2013-2014, agreed (in most cases) in 2014 and starting to be implemented during 2014-2016. During this period, donor ongoing and planned commitments reached the level of $€ 1.8$ billion (or $34 \%$ of the overall portfolio), respectively $€ 839$ million in $2014, € 521$ million in 2015 and $€ 434$ million in 2016.

\footnotetext{
${ }^{17}$ Foreign financing portfolio refers to ongoing, new and planned commitments for the
} period 2014-2016 


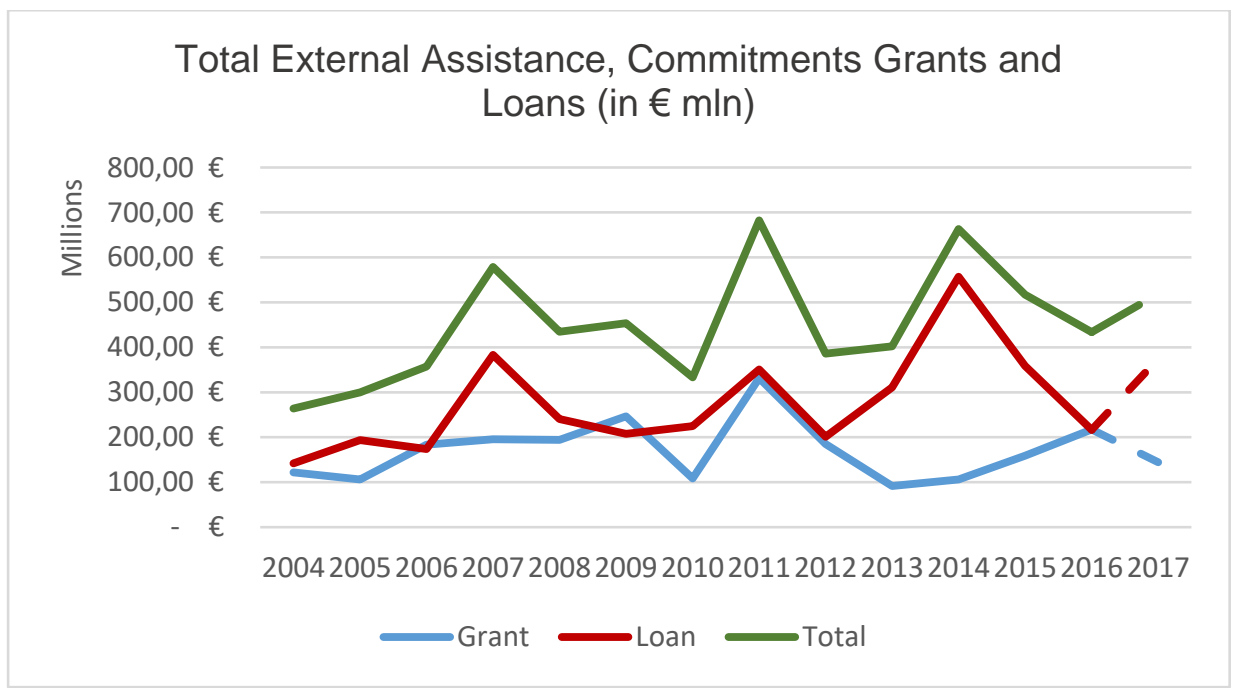

Figure 3: External Assistance, Commitments, Grants and Loans

In order to accelerate the pace of equitable growth, Government of Albania designed an ambitious program to implement structural reforms in order to raise productivity and competitiveness in the economy, create more jobs, and improve governance and public service delivery, as well as enhance regional connectivity and access to regional and global markets, coupled with export and market diversification.

To support this program, new donor commitments in the country increased significantly in 2014, mainly due to the new programming period starting from both government and donor side. This period was characterized by an intensive negotiation process for new strategies and protocols of cooperation with the main donors and IFIs, such as EU IPA II programming, IMF, World Bank CPF, Protocols of cooperation with Germany and Italy, preparation of new strategic frameworks with Swiss, Sweden etc. The programing process in support of government reforms continued during 20152016, however the total amount committed during this period decreased compared to 2014.

During 2014-2015, the level of Central Government debt increased up to $72.3 \%$ due to the recognition of unpaid obligations and invoices accumulated, and the whole weight of increase that was held by the external debt. The increase of external debt came as a result of the favorable conditions in external markets and as a result of Government's initiative to reduce the pressure of domestic borrowing and to give breath to the private sector crediting in Albania. However, the Government committed itself to lower the level of public debt to around 60\% in 2020 (IMF agreement signed in 2014). Starting from 2015, a significant decrease is noted regarding new commitments 
in loans, while committed level of grants during the same period increased significantly by $€ 217$ million.

The forecast on new commitments for 2017 shows an inverted trends between grants and loans. The level of disbursements have also increased significantly within the period 2014-2015 compared with the previous periods,

\section{Foreign Assistance by donors (multilateral and bilateral)}

Donor external assistance is an important instrument for the implementation of a series of projects that have a direct impact for a sustainable economic development of the country. Total assistance in Albania during 2014-2016 amounted to $€ 4.14$ billion, with an average rate of disbursement of $60 \% .69 \%$ is provided from 13 multilaterals and $31 \%$ from 12 bilateral donors.

For this period the five biggest multilateral development partners are: World Bank, European Union, Islamic Development Bank, International Monitoring Fund, European Bank for Reconstruction and Development, providing around $58 \%$ of the total assistance in the country.

The biggest bilateral donors are: Germany, Italy, Switzerland, USAID, Japan and Sweden providing 38\% of the total assistance.

The chart number 7 shows commitments 2014-2016 for multilateral and bilateral donors as shown in figure nr.

Committed vs Disbursed Foreign Assistanve, by Donors 20142016 (in $\mathrm{mln}$ )

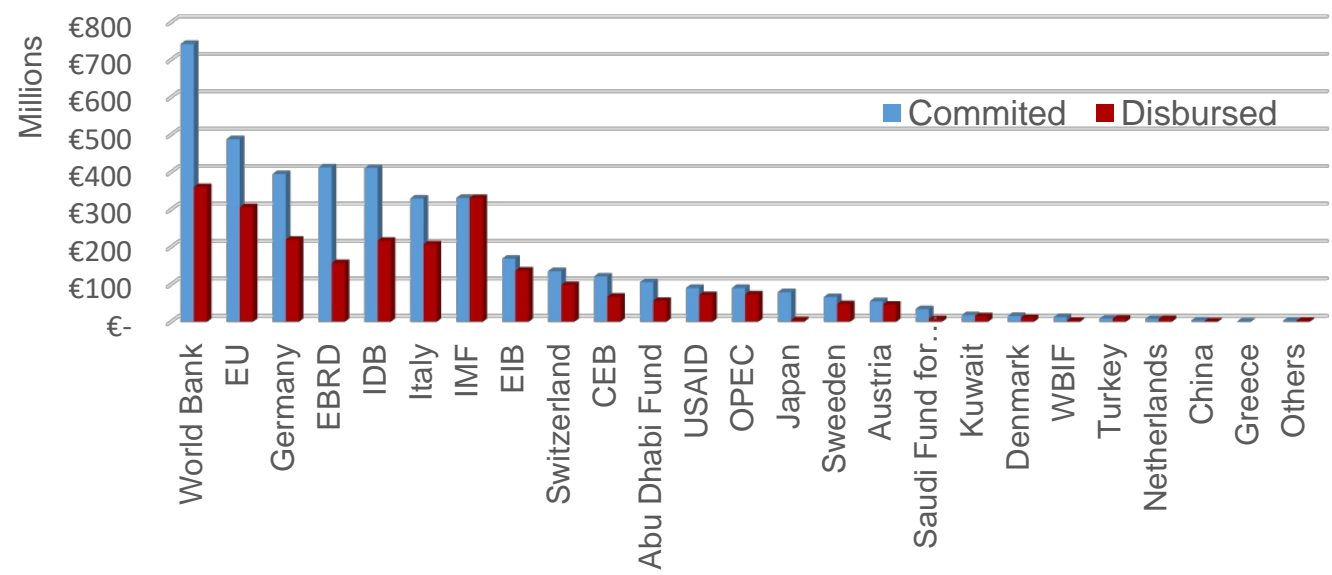

Figure 4: Committed vs Disbursed Foreign Assistance

\section{EU Foreign Assistance to Albania}

Since 2007 financial assistance provided from European Commission to Albania has been named Instruments for Pre-Accession (IPA) and covers 
the financial perspective 2007-2013. IPA I (2007-2013) has provided around 509 million EUR to Albania supporting the key priorities of the Government. Since 2014, Albania benefits financial assistance under IPA II programme that cover the period 2014-2020. Under IPA II programme, Albania will benefit a total indicative allocation of 649.4 million EUR. A Framework Agreement for IPA II prorgamme has entered into force in April 2014 financing the priorities of Albania as determined in the Country Strategy Paper. IPA II programing introduced a new novelty of financing through Budget Support as a new financial mode within the Public Finance Management- PFM of the country. The table below, shows the EU committed funds IPA II for the period 20142018 for Albania.

\section{OVERVIEW OF IPA ALLOCATION - 2014- 2018}

\begin{tabular}{|c|c|c|c|c|c|}
\hline ACTION PROGRAM & $\mathbf{2 0 1 4}$ & $\mathbf{2 0 1 5}$ & $\mathbf{2 0 1 6}$ & $\mathbf{2 0 1 7}$ & $\mathbf{2 0 1 8}$ \\
\hline TOTAL IPA Allocation (million EUR) & $\mathbf{6 8 . 7}$ & $\mathbf{9 1 . 9}$ & $\mathbf{8 2 . 4}$ & $\mathbf{8 0 . 8}$ & $\mathbf{8 7 . 8}$ \\
\hline $\begin{array}{c}\text { Democracy and governance } \\
\text { PFM Sector Reform Contract (SRC), } \\
\text { Technical assistance(TA) }\end{array}$ & $\mathbf{6 2 . 7}$ & $\mathbf{4 6 . 9}$ & $\mathbf{5 . 7 4}$ & $\mathbf{1 4 . 6}$ & $\mathbf{0}$ \\
\hline $\begin{array}{c}\text { Public Administration Reform SRC, TA } \\
\text { EU Integration Facility }\end{array}$ & 6.0 & 32 & 0 & 0 & 0 \\
\hline Union Programmes & 13.7 & 13.9 & 4.74 & 12.6 & 0 \\
\hline $\begin{array}{c}\text { Rule of law and fundamental rights } \\
\text { Support to econ-social. empowerment } \\
\text { of Roma }\end{array}$ & 4 & 1 & 1 & 2 & 0 \\
\hline $\begin{array}{c}\text { Consolidation of Justice system } \\
\text { (Euralius V, Monitoring of Vetting of }\end{array}$ & 0 & 0 & $\mathbf{2 2 . 5}$ & $\mathbf{0}$ & $\mathbf{5 2}$ \\
\hline $\begin{array}{c}\text { Judges, Justice SRC, TA) } \\
\text { Fight against corruption SRC+TA }\end{array}$ & 0 & 0 & 10 & 0 & 0 \\
\hline $\begin{array}{c}\text { Consolidation of Law Enforcement } \\
\text { Agencies: support to the Albanian State } \\
\text { Police and Prosecutor's Office }\end{array}$ & 0 & 13 & 0 & 0 & 0 \\
\hline Competitiveness and innovation & $\mathbf{0}$ & & & 0 & 52 \\
\hline Transport SRC, TA & 0 & 0 & 24 & 0 & 0 \\
\hline Water sector TA & 0 & 0 & 4 & 20 & 0 \\
\hline Employment SRC, TA & 0 & 30 & 0 & 0 & 0 \\
\hline Fishery and Food safety Action & 0 & 0 & 8.7 & $\mathbf{0}$ & $\mathbf{0}$ \\
\hline Tourism/ Local economic development & 0 & 0 & 0 & 27.2 & 12.8 \\
\hline TOTAL Annual Action Programme & $\mathbf{6 6 . 7}$ & $\mathbf{8 9 . 9}$ & $\mathbf{6 4 . 9}$ & $\mathbf{6 1 . 8}$ & $\mathbf{6 4 . 8}$ \\
\hline Other Programmes & $\mathbf{2}$ & $\mathbf{2}$ & $\mathbf{1 7 . 5}$ & $\mathbf{1 9}$ & $\mathbf{2 3}$ \\
\hline
\end{tabular}

Table 1:IPA II allocations per year per sector 


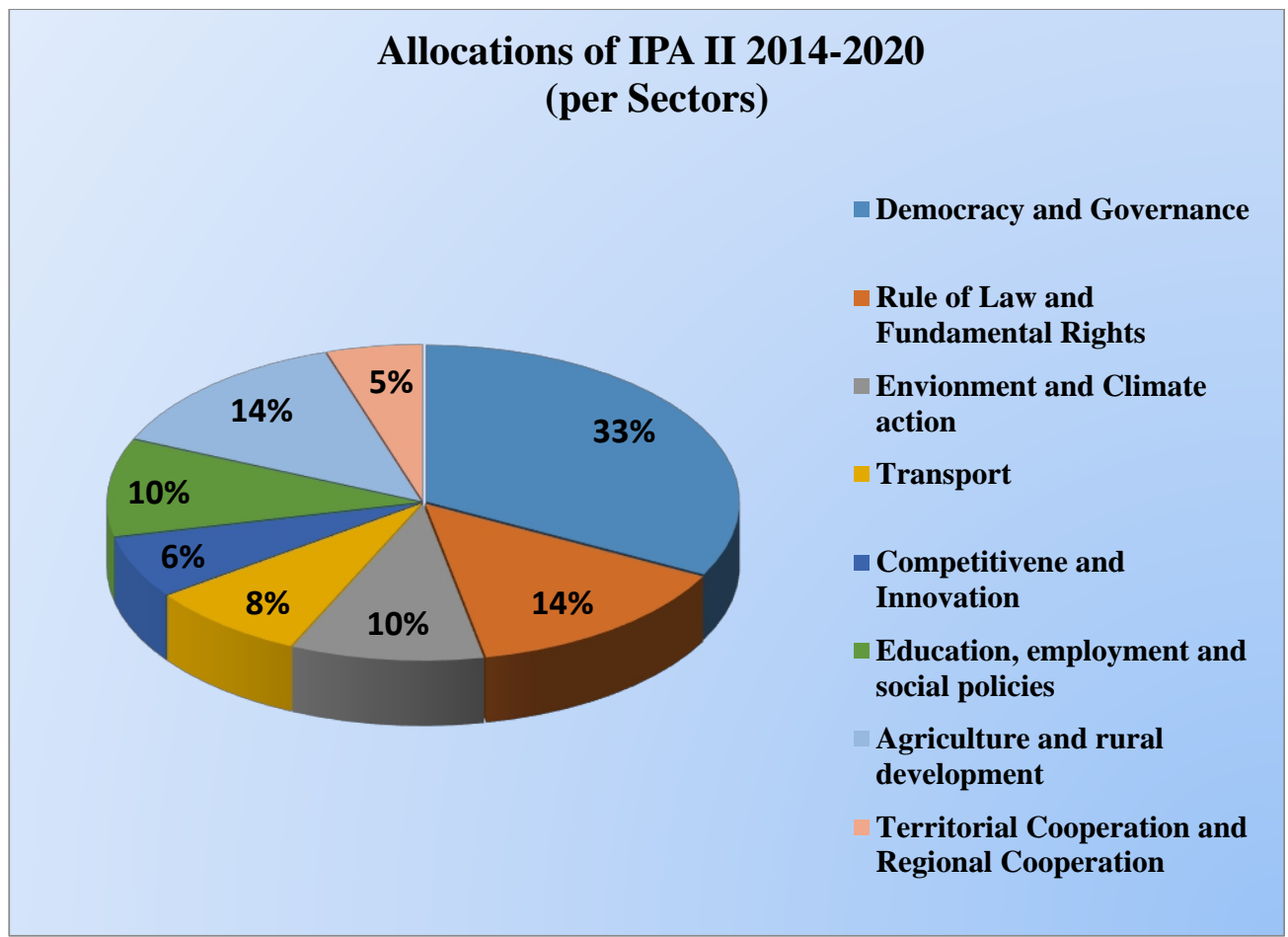

Figure 5: Allocations of IPA II per year and per sectors

\section{Difference from IPA I to IPA II}

In the year 2007 the European Union introduced a new financial instrument for candidate and potential candidate countries called Instrument for pre-accession (IPA) which covered financial assistance for a term of seven years (2007-2013). This assistance is provided on the progress made by the beneficiary countries and their needs shown in the evaluations and strategy papers by the EC. The financial assistance under IPA I was designed to address the needs of the beneficiary countries within the context of preaccession policy. The main aim of IPA is to support institution-building and the rule of law, human rights, including the fundamental freedoms, minority rights, gender equality and non-discrimination, both administrative and economic reforms, economic and social development, reconciliation and reconstruction, regional and cross-border cooperation and agriculture sector.To insure effectiveness of the priorities defined according to the needs of the beneficiary countries IPA is composed of five components; 1) Transitional Assistance and Institutional Building(TAIB), 2) Cross-Border Cooperation(CBC), 3) Human Resource Development (HRD), 4) Regional Development(RD) and 5) Rural Development or IPARD. The first two components concerns all beneficiary countries while the rest only to candidate countries. Therefore, until 2013 Albania could benefit only from the first two 
components, TAIB \& CBC. The amounts of EUR spread during this program and disbursement rate are shown in the tables below;

\begin{tabular}{|c|c|c|c|c|c|c|c|c|c|}
\hline Allocated & $\begin{array}{l}\text { IPA } \\
2007\end{array}$ & $\begin{array}{l}\text { IPA } \\
2008\end{array}$ & $\begin{array}{l}\text { IPA } \\
2009\end{array}$ & $\begin{array}{l}\text { IPA } \\
2010\end{array}$ & $\begin{array}{l}\text { IPA } \\
2011\end{array}$ & $\begin{array}{l}\text { IPA } \\
2012\end{array}$ & $\begin{array}{l}\text { IPA } \\
2013\end{array}$ & \multicolumn{2}{|c|}{ Total } \\
\hline & $\begin{array}{l}\text { Mill } \\
\text { Eur }\end{array}$ & $\begin{array}{l}\text { Mill } \\
\text { Eur }\end{array}$ & $\begin{array}{l}\text { Mill } \\
\text { Eur }\end{array}$ & $\begin{array}{l}\text { Mill } \\
\text { Eur }\end{array}$ & $\begin{array}{l}\text { Mill } \\
\text { Eur }\end{array}$ & $\begin{array}{l}\text { Mill } \\
\text { Eur }\end{array}$ & $\begin{array}{l}\text { Mill } \\
\text { Eur }\end{array}$ & $\begin{array}{l}\text { Mill } \\
\text { Eur }\end{array}$ & $\%$ \\
\hline $\begin{array}{l}\text { Justice and } \\
\text { home affairs }\end{array}$ & 15,6 & 9,4 & 10,7 & 18,7 & 17,3 & 23 & 19,5 & 114,2 & 22 \\
\hline $\begin{array}{l}\text { Public } \\
\text { administration } \\
\text { reform }\end{array}$ & 9,8 & 13.5 & 14,5 & 3,5 & 3,0 & 9,0 & 12,6 & 65,9 & 13 \\
\hline $\begin{array}{l}\text { Social } \\
\text { development }\end{array}$ & 0 & 7,4 & 1,3 & 3 & 4,3 & 6,2 & 4,5 & 26,7 & 5 \\
\hline Environment & 24 & 3 & 22 & 30 & 11,1 & 18,5 & 8 & 116,6 & 23 \\
\hline $\begin{array}{l}\text { Agriculture and } \\
\text { rural } \\
\text { development }\end{array}$ & 0 & 17,7 & 13 & 26,5 & 24,5 & 9,5 & 34,2 & 125,4 & 25 \\
\hline Transport & 0 & 7,6 & 0,0 & 0,0 & 19,4 & 9,3 & 2 & 38,3 & 8 \\
\hline Others & 0 & 2,3 & 8,4 & 1,5 & 2,4 & 6,1 & 1,2 & 21,9 & 4 \\
\hline Total & 49,4 & 60,9 & 69,9 & 83,2 & 82 & 81,6 & 82 & 509 & 100 \\
\hline
\end{tabular}

\begin{tabular}{|c|c|c|c|c|c|c|c|c|c|}
\hline Disbursed & $\begin{array}{l}\text { IPA } \\
2007\end{array}$ & $\begin{array}{l}\text { IPA } \\
2008\end{array}$ & $\begin{array}{l}\text { IPA } \\
2009\end{array}$ & $\begin{array}{l}\text { IPA } \\
2010\end{array}$ & $\begin{array}{l}\text { IPA } \\
2011\end{array}$ & $\begin{array}{l}\text { IPA } \\
2012\end{array}$ & $\begin{array}{l}\text { IPA } \\
2013\end{array}$ & \multicolumn{2}{|c|}{ Total } \\
\hline & $\begin{array}{l}\text { Mill } \\
\text { Eur }\end{array}$ & $\begin{array}{l}\text { Mill } \\
\text { Eur }\end{array}$ & $\begin{array}{l}\text { Mill } \\
\text { Eur }\end{array}$ & $\begin{array}{l}\text { Mill } \\
\text { Eur }\end{array}$ & $\begin{array}{l}\text { Mill } \\
\text { Eur }\end{array}$ & $\begin{array}{l}\text { Mill } \\
\text { Eur }\end{array}$ & $\begin{array}{l}\text { Mill } \\
\text { Eur }\end{array}$ & $\begin{array}{l}\text { Mill } \\
\text { Eur }\end{array}$ & $\%$ \\
\hline $\begin{array}{l}\text { Justice and } \\
\text { home affairs }\end{array}$ & 12,3 & 7,1 & 10,6 & 10,0 & 2,3 & 0,8 & 0,0 & 43,1 & 23 \\
\hline $\begin{array}{l}\text { Public } \\
\text { administration } \\
\text { reform }\end{array}$ & 8,9 & 12,6 & 12,7 & 2,0 & 0,8 & 0,0 & 0,0 & 37,0 & 20 \\
\hline $\begin{array}{l}\text { Social } \\
\text { development }\end{array}$ & 0 & 5,1 & 1,2 & 2,0 & 0,8 & 0,0 & 0,0 & 9,1 & 5,0 \\
\hline Environment & 15,8 & 2,7 & 5,9 & 5,3 & 0,0 & 0,0 & 0,0 & 29,7 & 16 \\
\hline $\begin{array}{l}\text { Agriculture } \\
\text { and rural } \\
\text { development }\end{array}$ & 0 & 15,2 & 9,0 & 9,7 & 8,8 & 0,0 & 0,0 & 42,7 & 23 \\
\hline Transport & 0 & 6,2 & 0,0 & 0,0 & 5,0 & 0,0 & 0,0 & 11,2 & 6 \\
\hline Others & 0 & 1,5 & 6,0 & 1,1 & 2,4 & 0,4 & 0,0 & 11,4 & 6 \\
\hline Total & 37,0 & 50,4 & 45,4 & 30,1 & 20,1 & 1,2 & $\mathbf{0 , 0}$ & 184,2 & 27,6 \\
\hline
\end{tabular}

Table 3: IPA 1 disbursement rate per year per sector

improvements in agriculture, infrastructure and cross border cooperation.

The new IPA approach which covers the period 2014-2020 and it differs from IPA I (2007-2013) because of its strategic approach. This new programme will provide for a stronger ownership by the beneficiaries through integrating their own reform and development agendas. In this regard, the EU 
will support Albania address and implement its Public finance management reform (2014-2020) as the Government priority for development and reforms. Reforming the public finances is like reforming the state as it involves many institutions and stakeholders. Under IPA II (2014-2020) the EU is intended to give Budget Support (BS) to Albania in order to implement sector reform in the public finance management, sector budget support in public administration reforms, VET, transport, Justice and Tourism and Environment. As seen by the data the amount of financial assistance provided under budget support, has set strict indicators which are not meet, therefore disbursement rates only for the implementation of PFM Reforms has been $30 \%$ of 30 Mill Eur available. However their actions are still under implementation.

\section{Conclusion and Recommendations:}

There seem from the observations the low rate of absorption of these funds. As to say that over the year's financial aid provided by EU has not had any spectacular successes to demonstrate, however significant progress has shown on the support to Public Administration reforms, Justice and Environment and Transport. There have been many researchers over the topics but they all get diverse results. Mostly and over the years, a number of problems have affected Albanian's absorption capacity of IPA funds that are mainly related to bureaucratic obstacles from authorities, lack of competent staff the implementation and the sustainability of the project designs. The effectiveness of the usage of IPA funds is a complex issue that needs detailed and further research on the problematics behind this low absorption rate.

It is recommended that the Albanian Authorities increase their awareness and motivate the staff working on IPA funds by designing proper retention policy and an annual training plan to increase the absorption capacity due to complexity of IPA procedures. It is recommended that the Government uses the IPMG Mechanism to monitor in frequent bases and take precautions on the problematics related to IPA usage. Therefore it requires enforcement of the mechanism as to establish a high level working group of the actors dealing with these issues.

\section{References:}

1. Clemens, M., and Redlet, S. 2003 "Absortive capacity;How much is too much”, in : Challenging Foreign Aid; A policymakers Guide to the Millenium Challenge Account, ed Radelet, Steven, Washington,DC; Center for Global Development

2. Horvat, A.2005." Why nobody cares about absorption, Vienna, WIFO working papers, No.258

3. EU Commission, Indicative Strategic Paper for Albania (2014-2020) 
4. Framework agreement between European Commission and Albania on the arrangements for implementation of union financial assistance to the Republic of Albania under the instrument for pre-accession assistance (IPA II)

5. Albanian Policy Paper Draft-Systemic Analysis of the Existing IPMG Structure \& Considerations on the Delineation of new IPMGs - Albania Global Partnership Monitoring - presentation for DIP Meeting 11/2016, Albania_21_10

6. Bailey, D. and L. De Propis (2004), 'A Bridge Too Phare? EU PreAccession Aid and Capacity-Building in the Candidate Countries', Journal of Common Market Studies,42, 1, 77-98.

7. http://www.financa.gov.al/en/reports/budget/1475565569/146468355 1/1478686917

8. https://ec.europa.eu/neighbourhoodenlargement/sites/near/files/pdf/Al bania/ipa/2013/centralised/ipa_2013_024190_multi_donor_trust_fund to_support_implementation_of_integrated_planning_system_pha.pdf

9. Donor Database Euro - 6 May 2014 from DDC

10. Donor Database 15.09.2016 from DDC

11. http://documents.worldbank.org/curated/en/602151467991993190/pdf 198254-CAS-P147570-PUBLIC-Box393168B.pdf

12. http://www.imf.org/external/np/sec/pr/2014/pr1481.htm

13. http://ec.europa.eu/enlargement/pdf/key_documents/2014/20140919csp-albania.pdf

14. Strategjia Kombetare per Zhvillim dhe Integrim 2015-2020

15. Absorption capacity of EU funded projects/prorgammes in Albania - A literature review, paper by Jola Himci Kepi published in 2nd International Conference on Banking and Finance Perspectives April 21 2017, Famagusta, North Cyprus 